\title{
PENINGKATAN PERTUMBUHAN EKONOMI MELALUI PENDIRIAN BAITUL TAMWIL MUHAMMADIYAH (BTM) BAGI MASYARAKAT PASAR RUMPUT JAKARTA SELATAN
}

\author{
Arif Fitriyanto, Adi Rianto, Abdul Azis Muslim, Irene Fitria Ningrum, Susan \\ Kusumawati, Saifan Zaking, Tisa Maulia, Tiara Afiyanti, \\ Yogi Restu Apriyadi, Yolanda Amelia Priyana \\ Universitas Muhammadiyah Prof. DR. HAMKA \\ Email: arief_uhamka1205@yahoo.com
}

Diterima: 10 Januari 2018, Direvisi: 18 Januari 2018, Disetujui: 30 Januari 2018

\begin{abstract}
ABSTRAK
Keinginan untuk melakukan kegiatan wirausaha sering tersendat tersendat karena keterbatasan modal dan tidak adanya badan usaha yang mau meminjamkan dana kepada calon pelaku usaha. Sekalinya ada pinjaman terkadang ada syarat pengembalian yang cukup tinggi sehingga merugikan mereka. Keadaan inilah yang menjadi latar belakang diadakannya program pengabdian masyarakat ini. Program pengabdian kepada masyarakat ini bertujuan untuk membantu masyarakat yang ingin membuka usaha namun memiliki keterbatasan modal dan melakukan pendampingan atau pelatihan usaha untuk meminimalisir kerugian yang akan timbul nantinya dengan cara mendirikan Baitul Tanwil Muhammadiyah (BTM) yang berbasis syariah dan tidak menerapkan sistem riba. Tulisan ini bertujuan untuk memaparkan kegiatan program pengabdian masyarakat yang dilakukan dalam rangka meningkatkan pertumbuhan ekonomi masyarakat Pasar Rumput Jakarta Selatan.
\end{abstract}

Kata kunci: BTM, pertumbuhan ekonomi, riba, rentenir dan wirausaha.

\begin{abstract}
Desire to engage in enterpreneurial activity often faltred because of limitations capital and the absence of a business entity that lends funds to them at no interest cost (usury) except for loan sharks which actually discourages them to entrepreneurship. This situation made us moved to help people who want to open a business but have limited capital or business funds and help the local community there to provide assistance or business training to minimize the losses that will arise later by establishing Baitul Tanwil Muhammadiyah (BTM) which is certainly based on sharia and not apply the usury system. This paper aims to describe the activities of community service programs undertaken in order to improve the economic growth of the people of Pasar Rumput South Jakarta.
\end{abstract}

Keywords: BTM, economic growth, usury, loan shark and entrepreneurship 
http://journal.uhamka.ac.id/index.php/syukur/index

\section{PENDAHULUAN}

Dalam kehidupan sehari-hari kita tidak lepas dari kegiatan ekonomi. Kegiatan ekonomi tersebut dimaksudkan untuk memenuhi kebutuhan kehidupan kita sehari-hari. Kegiatan ekonomi setiap individu tentunya berbeda dengan individu lain. Salah satu kegiatan tersebut adalah berwirausaha atau berdagang. Jakarta merupakan salah satu kota yang cukup ramai para pelaku bisnis. Bisnis yang dijuluki pun beragam mulai dari pedagang pakaian, sayur mayur dan sebagainya. Namun, tanpa disadari kegiatan ekonomi yang dilakukan masyarakat masih bermodalkan dari para rentenir yang menggunakan sistem riba pada masyarakat yang meminjam uangnya. Salah satunya adalah daerah di Jakarta Selatan, yakni Pasar Rumput. Pasar Rumput merupakan salah satu wilayah yang berada di daerah DKI Jakarta tepatnya daerah Jakarta Selatan berlokasi di Jalan Sultan Agung Jakarta Selatan Kelurahan Pasar Manggis.

Nama Pasar Rumput berasal dari tempat dimana para pedagang pribumi menjual rumput. Bisnis pasar rumput ini mengalami puncaknya pada tahun 1970-an. Namun, pada akhir periode tahun tersebut pedagang rumput mulai hilang satu per satu.Hal ini dikarenakan sudah mulai banyaknya masyarakat yang mempunyai kendaraan bermotor sehingga para penjual beralih ke penjual barang bekas (loak), yang sebelumnya memang sudah ada beberapa yang berjualan di pasar Ciliwung (Shahab, 2004).

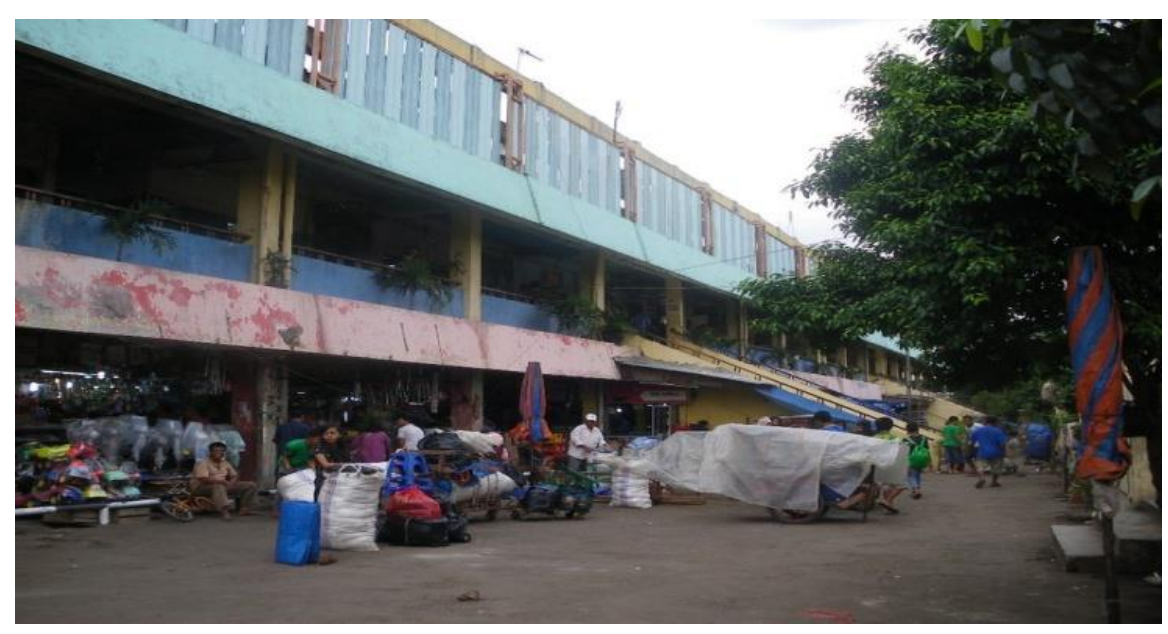

Gambar 1:

Aktivitas Pasar Rumput

Arif Fitriyanto: Peningkatan Pertumbuhan Ekonomi melalui 
Bisnis barang bekas di Pasar Rumput kian hari kian marak, hingga saat ini. Berbagai macam alat bekas dijual disini, seperti alat olahraga, perkantoran, sepeda bekas dan lain sebagainya (Abdila, 2015). Pasar ini menjadi tempat berburu bagi para pembeli dengan harga yang cukup murah. Seiring dengan perkembangannya, kini Pasar Rumput memiliki beberapa perubahan, namun daerah ini masih butuh perhatian yang khusus dari pemerintah. Menurut Rudi (2016) daerah ini masih jauh dari kelayakan air bersih karena air dari kali ciliwung sudah tidak bersih seperti tahun 1920-an dahulu, sungai ini sudah banyak tercemar oleh limbah serta sampah dari masyarakat sekitar dikarenakan pula sulitnya akses pembuangan sampah bagi masyarakat sehingga mereka membuang sampah di sungai.

Masalah inti dari daerah ini adalah kegiatan ekonominya. Dikarenakan area mereka yang berdekatan dengan pasar maka kegiatan ekonomi mereka pun tidaklah jauh dari pasar, kecuali bagi penduduk pendatang yang sudah memiliki pekerjaan tetap. Penghasilan yang tidak menentu dari pasar terkadang membuat masyarakat mengalami kerugian bahkan gulung tikar. Untuk membangun usaha baru, bukanlah hal mudah bagi mereka, keberadaan badan usaha yang memberikan pinjaman modal usaha pun tidak ada. Hanya ada keberadaan rentenir disana. Rentenir pun dianggap sangat memberatkan mereka. Sehingga membuat masyarakat untuk berfikir kembali mendirikan usaha. Karena, pengembalian uang yang lebih besar disbanding dengan uang yang mereka pinjam.

Kegiatan pengabdian masyarakat yang dilakukan oleh mahasiswa Fakultas Ekonomi dan Bisnis, Universitas Muhammadiyah Prof. DR. HAMKA terhadap masyarakat Pasar Rumput Jakarta Selatan ini bertujuan untuk membantu masyarakat meningkatkan pertumbuhan ekonomi dengan cara mendirikan badan simpan pinjam modal usaha tanpa bunga (riba) yang dikenal dengan nama BTM (Baitul Tamwil Muhammadiyah). Pendirian BTM ini bekerja sama dengan Pimpinan Cabang Muhamadiyah (PCM) Pasar Rumput melalui majlis ekonomi, yaitu Bapak Sridjoko.

Baitul Maal wa Tamwil (BMT) adalah lembaga keuangan yang bergerak pada level mikro yang operasinya pada prinsip-prinsip berekonomi secara halal, adil dan menguntungkan. BMT menjalankan perannya secara fenomenal dalam mengelola investasi (berupa modal, tabungan dan titipan) dan menghubungkannya dengan 
pembiayaan untuk mendorong pergerakan sektor usaha kecil. Selain itu, BMT juga berperan sebagai baitul maal (peran sosial) yang mendistribusikan modal dari yang punya kepada yang membutuhkan serta lembaga bisnis yang bermotif laba (Sumiyanto, 2008). Dari pengertian tersebut, dapatlah ditarik suatu pengertian yang menyeluruh bahwa BMT adalah organisasi bisnis yang juga berperan sosial. Fungsi BMT sebagai intermediasi bisnis dengan memanfaatkan investor akan sangat efektif jika diterapkan dalam kondisi masyarakat dengan ekonomi menengah ke bawah. Hal ini mengingat kondisi Sumber Daya Manusia (SDM) yang sudah melimpah, maka harus ada alat atau sarana untuk memberdayakan masyarakat dalam bidang ekonomi. Dengan visi pencerdasan masyarakat di bidang ekonomi syariah dan menciptakan masyarakat yang adil dan sejahtera, peran kelembagaan BMT menjadi strategis dalam mencapai visi tersebut.

Sehingga, pendirian BTM ini diharapkan tidak hanya dapat membantu masyarakat untuk meminjam dana tanpa bunga namun juga dapat memberikan pendampingan serta pelatihan-pelatihan wirausaha kepada masyarakat yang dikelompokkan sesuai minatnya. Pendampingan ini dilakukan hingga masyarakat benar-benar bisa menjalankan usahanya secara mandiri.

\section{METODE}

Pelaksanaaan pengabdian kepada masyarakat ini dilakukan melalui tahapan pelaksanaan mulai dari tahap persiapan, pelaksanaan, dan pelaporan. Untuk lebih jelasnya, berikut tahapan dan metode yang digunakan.

\section{Tahap Pra Observasi}

Pada tahap ini tim melakukan berbagai persiapan antara lain: pertama, pembekalan materi. Tim pengabdian yang terdiri dari para mahasiswa diberikan materi terlebih dahulu oleh dosen pendamping kelas. Materi terfokus pada dua hal: masalah filantropi, termasuk teknik-teknik fundraising dan teknik pemberdayaan masyarakat. Kedua, melakukan persiapan untuk turun lapangan dengan koordinasi dan penyiapan sarana pendukung yang dibutuhkan. 


\section{Tahap Observasi}

Tim pengabdian kepada masyarakat melakukan observasi ke beberapa titik di wilayah Pasar Rumput untuk memastikan apakah sasaran kegiatan yang akan dilakukan sesuai dengan kebutuhan masyarakat sekitar. Untuk memudahkan proses observasi, tim bekerjasama dengan tokoh masyarakat setempat dan pimpinan Muhammadiyah.

\section{Pengolahan Data}

Pengolahan data yang dimaksud adalah menganalisa data-data hasil observasi untuk menentukkan langkah tindak lanjut dan mencari solusi permasalahan. Masing-masing tim melakukan analisis data untuk kemudian dilakukan analisis gabungan.

\section{Tahap Koordinasi}

Hasil analisis di atas kemudian dikoordinasikan dengan berbagai pihak di lapangan untuk kemudian direalisasikan. Tim berkoordinasi dengan Pimpinan Cabang Muhammadiyah Pasar Rumput dan para tokoh masyarakat. Tim juga melakukan koordinasi dengan Majelis Ekonomi dan Majelis Pendidikan Muhammadiyah untuk merealisasikan program yang telah digagas berdasarkan hasil analisis di atas.

\section{MASALAH}

Daerah Pasar Rumput ini sedang mengalami perbaikan sedikit demi sedikit. Dimulai dari tata kelola wilayah dan pemukiman. Hanya saja, pembangunan yang dilakukan tidak begitu memperhatikan keadaan masyarakat sekitar. Seperti halnya pendirian pasar sayur-mayur yang tidak memiliki tempat pembuangan sampah sehingga mengganggu sistem pernafasan dan keasrian wilayah. Selain itu, kebaradaan air bersih yang masih sangat minim atau pun jamban yang dimiliki oleh masyarakat masih banyak yang dapat dikatakan belum layak untuk digunakan. Keberadaan pribumi yang semakin terkikis oleh pendatang yang memiliki modal usaha untuk berwirausaha membuat daerah ini dipadati oleh para pendatang yang sekedar "numpang" berwirausaha. Sebagian pribumi hanya sebagai buruh bahkan ada pula pengangguran. Masih dapat dihitung dengan jari berapa orang pribumi yang sudah memiliki pekerjaan tetap. 
Penelitian yang dilakukan oleh Fakultas Ekonomi dan Bisnis yang berjudul "Pembangunan Baitu Tamwil Muhammadiyah (BTM) bagi Masyarakat Pasar Rumput untuk Meningkatkan Pertumbuhan Ekonomi Berbasis Syariah menuju Masyarakat Mandiri" menegaskan bahwa pembangunan BTM dapat menjadi solusi yang tepat bagi masyarakat sekitar Pasar Rumput. Hal ini dimaksudkan untuk memudahkan masyarakat dalam mendapatkan dana untuk mendirikan modal usaha serta menjauhkan masyarakat dari unsur riba dengan harapan mampu menghentikan keberadaan serta ketergantungan masyarakat terhadap rentenir. Selain itu, pendirian BTM ini dapat meningkatkan pertumbuhan ekonomi Pasar Rumput serta mengurangi tingkat pengangguran.

\section{HASIL DAN PEMBAHASAN}

Daerah Pasar Rumput ini sedang mengalami perbaikan sedikit demi sedikit, mulai dari tata kelola wilayah dan pemukiman hingga perbaikan ekonomi. Hanya saja, pembangunan yang dilakukan tidak begitu memperhatikan keadaan masyarakat sekitar. Seperti halnya pendirian pasar sayur-mayur yang tidak memiliki tempat pembuangan sampah sehingga mengganggu sistem pernafasan dan keasrian wilayah. Selain itu, kebaradaan air bersih yang masih sangat minim atau pun jamban yang dimiliki oleh masyarakat masih banyak yang dapat dikatakan belum layak untuk digunakan. Keberadaan pribumi yang semakin terkikis oleh pendatang yang memiliki modal usaha untuk berwirausaha membuat daerah ini dipadati oleh pendatang yang sekedar numpang berwirausaha. Sebagian pribumi hanya sebagai buruh bahkan adapula pengangguran. Masih dapat dihitung dengan jari berapa orang pribumi yang sudah memiliki pekerjaan tetap.

Penelitian yang dilakukan oleh Fakultas Ekonomi dan Bisnis menegaskan bahwa pembangunan Baitu Tamwil Muhammadiyah (BTM) dapat menjadi salah satu solusi untuk meningkatkan perekonomian masyarakat Pasar Rumput. BTM akan memudahkan masyarakat dalam mendapatkan dana untuk menidirkan modal usaha serta menjauhkan masyarakat dari unsur riba dengan harapan mampu menghentikan keberadaan serta ketergantungan masyarakt terhadap rentenir. Selain itu, pendirian BTM ini dapat meningkatkan pertumbuhan ekonomi pasar rumput serta mengurangi tingkat pengangguran. Memperhatikan kondisi lokasi dan masyarakat Pasar Rumput, maka 
konsep pemberdayaan masyarakat yang sesuai secara umum adalah melalui pendekatanpendekatan kepada masyarakat untuk mengenalkan tentang dan tujuan BTM ini.

Untuk melakukan pembangunan BTM, tim pengabdian masyarakat melakukan diskusi pada hari Sabtu, 20 Mei 2017 bertempat di kampus A UHAMKA Limau lantai 4 Ruang 401 pukul 15.00-16.00 dengan notulen Tisa Maulia. Hasil diskusi tersebut menyusun beberapa draft kuesioner kepada masyarakat yang akan disampaikan melalui melalui wawancara dengan membentuk 3 tim, dimana satu tim berisikan 3-4 anggota.

Selanjutnya melakukan observasi yang dilaksanakan pada hari Ahad, 21 Mei 2017 di wilayah Pasar Rumput. Tim melakukan observasi dengan mengunjungi kediaman Kepala Rukun Warga Pasar Rumput. Pada observasi pertama, tim berhasil mengunjungi kawasan RW 12, RW 6 dan RW 2. Tahap observasi ini bertujuan untuk memastikan apakah program yang dirancang benar-benar sesuai dengan kebutuhan masyarakat. Karena ingin mendapatkan hasil yang maksimal, maka tim melakukan kegiatan observasi sebanyak 2 kali, yaitu pada tanggal 21 Mei 2017 dan 25 Mei 2017. Selanjutnya, pada tanggal 25 Mei 2017 tim mengunjungi wilayah RW 1, RW 3 dan RW 5 serta beberapa pemukiman warga.

Dari hasil observasi, kemudian melakukan pengolahan data yang dilaksanakan pada tanggal 27 Mei 2017. Pengolahan data ini dilaksanakan dengan cara membacakan serta memberi penjelasan dari hasil observasi yang telah dilakukan setiap timnya. Adapun gambaran umum mengenai hasil wawancara yang telah dilaksanakan, yaitu

1) Hampir keseluruhan masyarakat mengeluhkan tentang kesulitan kegiatan ekonomi berupa modal atau biaya usaha mereka. Dikarenakan, keuntungan yang mereka dapatkan dari pasar tidak menentu sehingga mereka tidak dapat memprediksikan pengembalian modal dari usaha.

2) Tingkat pendidikan yang rendah merupakan salah satu alasan mengapa mereka memilih untuk berjualan di pasar.

3) Ketergantungan ekonomi mereka kepada rentenir yang merupakan ujung daripada solusi mereka ketika tidak mempunyai cadangan simpanan untuk kelangsungan usaha bahkan untuk membiayai makan sehari-hari. Namun, rentenir pun seperti mencekik mereka dengan memberi sistem bunga pinjaman hampir 30 persen dari pinjaman mereka. 
http://journal.uhamka.ac.id/index.php/syukur/index

4) Masyarakat yang memiliki taraf hidup cukup di daerah Pasar Rumput merupakan para pendatang yang membeli tanah pribumi.

5) Sosialisasi serta keberadaan instansi pemerintah mengenai simpan pinjam modal usaha sangatlah minim dan prosesnya sangat berbelit sehingga masyarakat enggan berminat.

Dari beberapa point di atas, tim selanjutnya bekerja sama dengan tokoh masyarakat dan Pimpinan Cabang Muhammadiyah (PCM) Pasar Rumput untuk membantu masyarakat terutama dalam hal modal usaha. PCM sangat antusias dan mendukung program pendirian BTM yang digagas oleh tim pengabdian masyarakat. Ternyata program ini sebelumnya juga telah pernah digagas oleh PCM, namun belum sempat direalisasikan. Jadi ada kesamaan visi diantara kami. Berikut tabelnya:

Tabel 1:

Rangkaian Koordinasi dengan Pihak PCM

\begin{tabular}{|l|l|l|l|}
\hline No & Tanggal Pertemuan & Agenda & Hasil Pertemuan \\
\hline 1 & 30 Mei 2017 & $\begin{array}{l}\text { Pemaparan maksud dan } \\
\text { tujuan PKM }\end{array}$ & $\begin{array}{l}\text { Mendirikan BTM dan } \\
\text { kelembagaannya }\end{array}$ \\
\hline 2 & 9 Juni 2017 & Rapat bersama PCM & $\begin{array}{l}\text { Langkah-langkah untuk pendirian } \\
\text { BTM serta Fundrising }\end{array}$ \\
\hline 3 & 14 Juni 2017 & Buka Puasa Bersama & $\begin{array}{l}\text { Strategi sosialisasi masyarakat } \\
\text { dan pemaparan progress }\end{array}$ \\
\hline 4 & 30 Juli 2017 & Halal Bihalal & $\begin{array}{l}\text { Launching dan penyampaian } \\
\text { BTM }\end{array}$ \\
\hline 5 & 15 Agustus 2017 & Silaturahmi & $\begin{array}{l}\text { Penyerahan Aset dan } \\
\text { keberlanjutan kegiatan }\end{array}$ \\
\hline
\end{tabular}

Tanggal 30 Juni 2017 BTM berhasil didirikan dan dilaunching dalam acara halal bihalal Hari Raya Idul Fitri. Namun demikian pendirian BMT ini belumlah cukup. Masih banyak masyarakat yang belum tahu seluk-beluk, bahkan keberadaan BTM ini. Untuk itu tim, bekerjasama dengan Pimpinan Cabang Muhammadiyah melakukan sosialisasi kepada masyarakat. PCM juga mempromosikan BTM ini kepada masyarakat yang dilanjutkan dengan kegiatan penyuluhannya pada tanggal 1 Agustus 2017 di Masjid at-Taqwa sekaligus melaksanakan kegiatan pengajian bulanan. Setidaknya sudah ada 20 anggota yang mendaftar untuk mengikuti kelas pendampingan yang akan dilaksanakan oleh PCM. Karena itu, BTM ini tidak hanya memberi pinjaman namun 
juga memberi pendampingan untuk masyarakat yang ingin mengasah kemampuannya sampai mendapatkan dana usaha melalui BTM.

\section{KESIMPULAN}

Berdasarkan uraian di atas, dapat disimpulkan beberapa hal penting sebagai berikut. Pertama, hasil pengabdian masyarakat mengahasilkan dampak positif bagi lingkungan masyarakat Pasar Rumput. Hal ini dapat dilihat dari antusias masyarakat yang mengikuti program pendampingan usaha. Kedua, sebagai salah satu bagian dari kader Muhammadiyah, setidaknya ini merupakan bakti kepada Muhammadiyah dalam bentuk amal usaha Muhammadiyah. Ketiga, dengan adanya BTM ini mampu meringankan beban masyarakat dalam ekonomi serta memutus mata rantai rentenir yang menjerumuskan masyarakat ke dalam dalam praktik riba. Keempat, peningkatan pemasaran BTM ini masih sangat diperlukan mengingat BTM ini baru merintis dan masih butuh berbagai masukan dari semua pihak agar berjalan sesuai yang diharapkan.

\section{DAFTAR PUSTAKA}

Abdila R. 2015. Blusukan ke Pasar Rumput, Pusat Barang Bekas Kualitas Berharga Murah, Mulai Kloset hingga Sepatu. Diakses pada http://www.tribunnews.com/travel/2015/09/18/blusukan-ke-pasar-rumput-pusatbarang-bekas-kualitas-berharga-murah-mulai-kloset-hingga-sepatu (21 Januari 2018).

Ismail GA. 2016. BMT Praktik dan Kasus. Yogyakarta: Rajawali Press.

Mulia R. 2015. Kesehatan Lingkungan. Jakarta: Graha Ilmu.

Rudi A. 2016. Delapan Sungai di Jakarta Tercemar. Diakses dari http://megapolitan.kompas.com/read/2016/05/20/16410211/delapan.sungai.di.jaka rta.tercemar (22 Januari 2018).

Shahab A. 2004. Betawi Queen Of The East. Jakarta: Republika.

Singarimbun M. 1998. Metodologi Penelitian Survey: Edisi Revisi. Jakarta: LP3ES.

Sugiyono. 2008. Metode Penelitian Kuantitatif, Kualitatif dan $R \&$ D. Bandung: ALFABETA.

Sumiyanto A. 2008. BMT Menuju Koperasi Modern. ISES Publishing: Yogyakarta.

Sutopo HB. 2006. Metode Penelitian Kualitatif. Surakarta: UNS Press. 